\title{
金沢市用水保全審議会による用水の多様な利用と管理 の即地的な調整に関する研究
}

\author{
Study regarding the coordination of multifunctional use and management for each canal water \\ conservation by the Kanazawa City Canal Water Council
}

\author{
坂村 圭* 北畠 拓也* \\ Kei SAKAMURA Takuya KITABATAKE
}

\begin{abstract}
This study focused on local policy regarding canal water conservation of Kanazawa City. The purpose of this study was an analysis of the impact made by the content of deliberations held to coordinate multifunctional use and management of the water on actual conservation standards and maintenance operations. Research methods included analyzing meeting minutes of the water conservation council and fact-finding interviews held in Kanazawa City. With respect to multifunctional use, conflicts over the conversion of canal water from agricultural use to urban use, as well as between creating habitat for fauna versus scenic and citizens' use were deliberated. Conservation standards were developed, and maintenance operations were implemented by coordinating around these conflicts. The study also analyzed the content of deliberations concerning coordination between usage and management of the canal water and site-specific conservation of canal locations, and the impact of those deliberations on the conservation standards.

Keywords : canal water, nature conservation, multifunction, city planning, Kanazawa city

キーワード：用水, 自然保全, 多面的機能, 都市計画, 金沢市
\end{abstract}

\section{1.はじめに}

\section{(1) 研究の背景と目的}

用水は，全国に約 40 万キロ以上にも及ぶ水のネットワークを 形成する貴重な地域資源の一つである。この用水は, 農業のため の利用だけでなく，都市部における自然と触れ合う機会の創出や， 生態系保全などの多面的な機能が期待されている ${ }^{1)}$ 。しかし，急 速な都市化の影響などから 1990 年をピークに農業のための用水 利用が減少しはじめると, それまで管理を行っていた農家や土地 改良区による適切な維持管理が困難となり, 用水や周辺環境が荒 廃するケースが顕在化するようになってきた ${ }^{2)}$ 。

このような背景から, 歴史や親水機能などを積極的に評価して 用水を保全する事業制度 ${ }^{3)}$ や, 農業用水が都市に与える環境機 能を評価して農家の管理負担を軽減する「環境用水」という水利 使用許可が認定されている ${ }^{4)}$ 。一方で, 自治体が依然として課題 としていることが，都市活動と用水の多面的な機能や管理コスト を調整して，具体的な整備方針を即地的に決定することである。 このような調整を持続的に行う一つの手段が, 自治体による用水 保全の制度策定であるが, 用水保全のための制度策定事例は全国 的に少なく，その運用の実態はあまり研究されていない5)。

本研究で対象とする金沢市は，用水保全の制度の運用に関して, 先進的な取り組みを行っている自治体の一つである。金沢市は, 全国で初めて金沢市用水保全条例を制定すると，積極的に用水の 保全と利用を推し進め, 2019 年までに 21 の保全用水を順次指定 してきた ${ }^{6)}$ 。これらの用水の保全指定に際しては, それぞれの用 水の社会的・歴史的な背景を考慮した保全基準が金沢市用水保全 審議会の協議をもとに決定され, 多様な利用や管理とのバランス が即地的に検討されている。そしてこの保全基準をもとに，金沢 市は, 暗渠化した用水を開渠化するハード面の取り組みや, 環境 や教育に関わるイベント補助などのソフト面の取り組みを行って いる。

このように, 本研究で着目するのは, 金沢市による協議型の用
水保全の制度設計と運用の取り組みである。本事例の制度や整備 実態に関する研究は, 山下 $(2018)^{7)}$ や林ら $(2012)^{8)}$ など複数 存在している。しかし用水保全条例の運用に関して, 審議会が都 市活動と用水の多面的な機能や管理コストをどのように調整し, 具体的な保全基準や整備事業の実施に影響を与えているのかを分 析した研究は存在していない。

そこで本研究では，金沢市の用水保全条例を対象に，これまで あまり論じられてこなかった用水保全制度の運用において中心的 な役割を果たしている審議会の実態を調査し, 多面的な利用と管 理を調整するために行われた協議の内容とそれが実際の保全基準 の策定と整備事業に与えた影響を分析することを目的とした。こ のように金沢市の審議会を中心とした用水保全の利用と管理を調 整する社会的な仕組みの実態を明らかにすることは，他地域での 協議型の用水保全の取り組みの展開や用水保全制度の構築に貢献 していくことだと考えている。

\section{(2) 本研究の位置づけ}

用水の多面的機能の発揮とその実現にむけた新たな整備・管理 手法に関しては, 用水施設整備上の検討課題 ${ }^{9}$, 多面的機能発揮 に関する管理コスト ${ }^{10)}$, 土地改良区の先進的取り組みと貢献内 容 ${ }^{11)}$, 住民の用水管理への参加のあり方 ${ }^{12)}$ など多角的に研究さ れている。このなかで本研究は, 自治体による都市部の用水保全 の制度設計とその運用に着目した研究である。自治体や公団によ る多面的機能の確保に向けた用水保全の取り組み事例は, 井上ら $(2002)^{13)}$ など複数存在しているが, 用水保全に関わる制度設計 とその運用に関する研究はあまりない。このなかで, 山下 $(2018)^{7)}$ は, 本研究で対象としている金沢市の用水保全条例に関して, 制 度策定までの経緯を詳細にまとめ, さらに用水の多面的利用の実 態を報告している。また，林ら $(2012)^{8)}$ は，金沢市による用水 の整備事業の実施状況と地域に与えた影響を分析している。しか しこれらの研究は, 用水保全条例の運用に際して, 具体的にどの ような協議を行うことで多様な利用と管理を即地的に調整してい

\footnotetext{
${ }^{*}$ 東京工業大学大学院 環境 - 社会理工学院 建築学系
} 
るかを分析したものではない。このように本研究は，保全基準策 定までの個別の議論を具体的に分析して, 自治体による協議型の 用水保全条例の運用の実態を明らかにする点に新規性がある。

なお，本研究で条例の運用の分析のために行った議事録調査は， 都市計画の協議型の制度運用の分析に際して既に広く用いられて いる ${ }^{14)}$ 。また，調査対象とした，金沢市の用水の経路や歴史を まとめたものとしては, 金沢市教育委員会 $(2000)^{15}$ ) が詳しく本 研究でも参照している。

\section{(3) 研究の方法}

本研究の方法は, 表一 1 のようにまとめられる。金沢市の用水 保全の施策の枠組みと保全方針は，金沢市から提供を受けた資料 や文献調查 ${ }^{16)}$ から把握した。また，用水の保全基準決定に至る 経緯は，金沢市から提供を受けた金沢市用水保全審議会の議事録 の審議内容を分析することで行った。この他に, 現在の維持管理 や利用に関して，金沢市の 3 つの関係部署に聞き取り調查を行っ ている。

\section{(4) 研究の構成}

本論文は, 全 5 章から構成される。続く 2 章では, 金沢市の用 水保全に関する地域政策を概観する。ここでは特に, 用水保全の

\section{表 -1 研究の方法}

\begin{tabular}{|c|c|c|c|c|c|}
\hline 調查目的 & $\begin{array}{l}\text { 調查 } \\
\text { 方法 } \\
\end{array}$ & 調查日時 & 調查対象 & 調查內容 & \\
\hline $\begin{array}{l}\text { 金沢市による用水保全 } \\
\text { の考え方とそと条例枠 } \\
\text { 組みの把握 }\end{array}$ & $\begin{array}{l}\text { 文献 } \\
\text { 調查 }\end{array}$ & $\begin{array}{l}\text { 2019年 } \\
10-12 \text { 月 }\end{array}$ & \begin{tabular}{|l} 
金沢市用水保全条例 \\
に関する行政文書
\end{tabular} & $\begin{array}{l}\text {-金沢市の用水保全の経緯 } \\
\text {-金沢市用水全条例の整借別針 }\end{array}$ & \\
\hline $\begin{array}{l}\text { 用水保全の整備方針策 } \\
\text { 定時に論点となった事 } \\
\text { 項とその解決策の把握 }\end{array}$ & $\begin{array}{l}\text { 文献 } \\
\text { 調査 }\end{array}$ & $\begin{array}{c}\text { 2019年 } \\
\text { 11月 }\end{array}$ & $\begin{array}{l}\text { 全28回の金沢市用水 } \\
\text { 保全審議会の議事録 }\end{array}$ & $\begin{array}{l}\text {-審議会の議題の推移 } \\
\text {-用水の多栐な利用の調整 } \\
\text {-用水の利用と管理の調整 }\end{array}$ & \\
\hline $\begin{array}{l}\text { 金沢市の用水の維持管 } \\
\text { 理と利用に関する施策 } \\
\text { の把握 }\end{array}$ & 调き調查 & \begin{tabular}{|c|} 
2019年 \\
11月20日
\end{tabular} & $\begin{array}{l}\text { 金沢市の用水管理関 } \\
\text { 係部局 (内水整備課 } \\
\text { 濃業基盤整備課/歴 } \\
\text { 都市推進課) }\end{array}$ & $\begin{array}{l}\text {-用水の管理体制とその内容 } \\
\text {-用水の利活用の推進 }\end{array}$ & \\
\hline
\end{tabular}

中心的な役割を担う用水保全条例の内容を説明し，この条例によっ

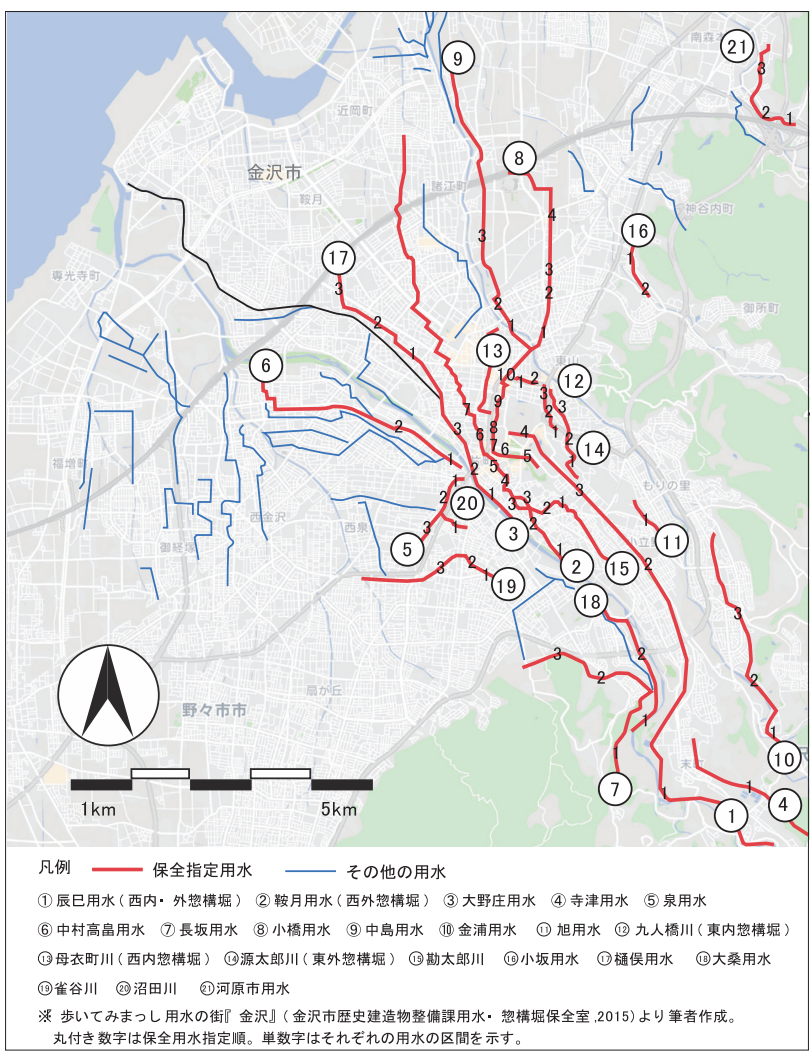

図-1 金沢市の用水の分布

\section{表 -2 金沢市保全用水の成り立ちと現在の利用}

\begin{tabular}{|c|c|c|c|c|c|c|}
\hline No. & 名称 & 完成年 & $\begin{array}{l}\text { 延長 } \\
\text { 距離 }\end{array}$ & \begin{tabular}{|l|l} 
区域 \\
区分
\end{tabular} & 成り立ち & 現在の利用 \\
\hline 1 & 辰巳用水 & 1632 & $16.5 \mathrm{~km}$ & $\begin{array}{l}\text { 市街+ } \\
\text { 調整 }\end{array}$ & $\begin{array}{l}\text { 1631年の大火を受け、三代藩主・利常の命で板屋兵四郎が完成させたと伝わる。防衛 } \\
\text { 上重視され、城内の飲料水を供給した。藩政後期に木管から石管に変更。大正期以降 } \\
\text { には水力発電や野菜洗い、精米に用いられた。 }\end{array}$ & 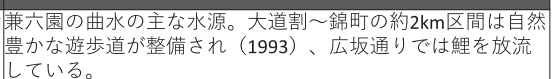 \\
\hline 2 & 鞍月用水 & 44 & $.6 \mathrm{~km}$ & $\begin{array}{l}\text { 市街+ } \\
\text { 調整 }\end{array}$ & 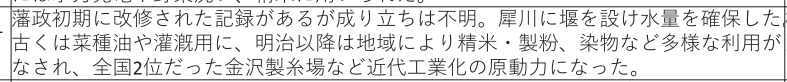 & $\begin{array}{l}\text { 柿木畠で開渠・ポケットパーク化 (1993) 、香林〜高岡町 } \\
\text { ので開渠化・私有橋の整理(1999) などが進み、中心市街地 } \\
\text { の㫿悬をつっている。 }\end{array}$ \\
\hline 3 & 大野庄用水 & 不明 & $10.2 \mathrm{~km}$ & 市街 & $\begin{array}{l}\text { 灌溉、物資運搬、防火、防御、融雪などの多目的な利用がなされ、金沢城築城に寄与 } \\
\text { した。旧宮腰（金石港）から木材を運び、荷揚げし木材蔵のある木倉町へ運搬してい } \\
\text { たため御荷川 } \\
\text { (鬼川) と呼ばれた。 }\end{array}$ & $\begin{array}{l}\text { 長町武家屋敷の土塀沿いを流れ、屋敷内庭園の曲水に利用 } \\
\text { されている。金沢の代表的な伝統景観を形成しており、近 } \\
\text { 年は蛍も生息する。 }\end{array}$ \\
\hline 4 & 寺津用水 & 1655 & $10.7 \mathrm{~km}$ & $\begin{array}{l}\text { 市街+ } \\
\text { 調整 }\end{array}$ & $\begin{array}{l}\text { 末町・土清水町の台地を灌溉するために造られ、非常に長く現存する隧道を通る。用 } \\
\text { 水の水を利用し、金沢市敢初の発電所・辰巳発電所が完成 }(1900) \text { 。 }\end{array}$ & $\begin{array}{l}\text { しても利用されており、周辺は自然豊かで、用水 } \\
\end{array}$ \\
\hline 5 & 泉用水 & 不明 & $2.8 \mathrm{~km}$ & 市街 & $\begin{array}{l}\text { も古い開削の記録は1705年でそれ以前は不明。旧米丸村増泉、旧三馬村泉・西 } \\
\text { 業用水として用いられた。宝院周辺に古くからの水路隧道坑門がある。 }\end{array}$ & $\begin{array}{l}\text { 糜史的な景観を残し、西茶屋近くでは橋ご } \\
\text { 違う市道橋が架かる。 }\end{array}$ \\
\hline 6 & 中村高畠用水 & $\begin{array}{l}1573 \\
\sim 92\end{array}$ & $4.5 \mathrm{~km}$ & 市街 & 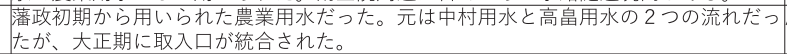 & $\begin{array}{l}\text { 犬見川閔を潤す複数の用水に分流。神田第1児童公園 } \\
\text { 法がる。 }\end{array}$ \\
\hline 7 & 長坂用水 & 1671年 & $7.4 \mathrm{~km}$ & $\begin{array}{l}\begin{array}{l}\text { 市街+ } \\
\text { 調整 }\end{array} \\
\end{array}$ & $\begin{array}{l}\text { 寺町台地一带の灌溉を目的として、藩命の下で着工(1667)。長坂新村の開村、泉野村 } \\
\text { の米作に寄与した。新内川ダムと上水道導水路完成に伴い水路が短縮 (1973)。 }\end{array}$ & $\begin{array}{l}\text { 上流部では竹林の間を流れるなど、自然のままの景観を留 } \\
\text { める。大乗寺筋にも陵付近かかれ。 }\end{array}$ \\
\hline 8 & 小橋用水 & $\begin{array}{c}1688 \sim \\
1704\end{array}$ & $3.9 \mathrm{~km}$ & $\begin{array}{l}\text { 市街+ } \\
\text { 調整 }\end{array}$ & $\begin{array}{l}\text { 城下町の防衛・都市用水の目的で築造。かつては浅野川が増水するごとに沈床（ドン } \\
\text { ドコ）を造っていた。昭和初期まで菜種油製造や精米・製粉のため水車が多数存在。 }\end{array}$ & $\begin{array}{l}\text { 元町第3児童公園には木製水車が設けられており、近隣の遊 } \\
\text { 歩道で散策を楽しむことができる。 }\end{array}$ \\
\hline 9 & 中島用水 & 1698 & $5.3 \mathrm{~km}$ & 調整 & 小橋用水と同様、防衛や都市用水の目的で藩により築造されたと伝えられている。 & $\begin{array}{l}\text { 市街地ではほとんど暗渠だが、沖町・磯部町を潤す農業用 } \\
\text { 水となる。 }\end{array}$ \\
\hline 10 & 金浦用水 & 不明 & $4.4 \mathrm{~km}$ & $\begin{array}{l}\text { 市街+ } \\
\text { 調整 }\end{array}$ & 藩政期〜明治中期に金浦郷と呼ばれた地域一帯を潤す農業用水だった。 & $\begin{array}{l}\text { 才近では民家の庭先に鑑賞用の水車が見 } \\
\text { 村風景を流れる。 }\end{array}$ \\
\hline 11 & 旭用水 & 不明 & $4.1 \mathrm{~km}$ & 市街 & $\begin{array}{l}\text { 藩政期より坂上からの眺望がよく、鶴間坂一帯の竹藪には風雅を好む人々が集った。 } \\
\text { 中腹の旭清水は周辺民家の飲み水に用いられたが、1 }\end{array}$ & $\begin{array}{l}\text { 昜、水面にかかる草花が見られ、背後の } \\
\text { 景観をつくる。 }\end{array}$ \\
\hline 12 & 九人橋川 & & $3 \mathrm{~km}$ & 市街 & 1610年から金沢城の防衛施設として築造され、消火や排水に用いられた。 & $\begin{array}{l}\text { 高さ4mの升形の土塁と } \\
\text { 境を今に伝える。 }\end{array}$ \\
\hline 13 & 母衣町川 & & $1.6 \mathrm{~km}$ & 市街 & 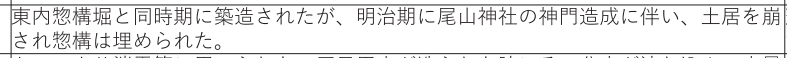 & していないが、主計町では惣構堀を復元し \\
\hline 14 & 源太郎川 & 不明 & $2.0 \mathrm{~km}$ & 市街 & $\begin{array}{l}\text { かつてより消雪等に用いられた。辰巳用水が造られた時にその分水が流れ込んで水量 } \\
\text { は豊富だった。音から、「とどあき橋」「百々女木町」と名付けられた。 }\end{array}$ & \\
\hline 15 & |勘太郎川 & 不明 & $1.4 \mathrm{~km}$ & 市街 & $\begin{array}{l}\text { 辰已用水の分流で戦後まで旧百姓町（幸町）・鱗町・本多町などに製系、精錬、精米 } \\
\text { 製粉業を営む家が多数あった。。 }\end{array}$ & $\begin{array}{l}\text { 現存する大清水（笠舞）の湧水と辰巳用水の分水などが合 } \\
\text { わさり、流れをを形成している。 }\end{array}$ \\
\hline 16 & 小坂用水 & 明 & $1.6 \mathrm{~km}$ & 市街 & $\begin{array}{l}\text { 奈良末期には「小坂鄊」、鎌倉期には荘園「小坂荘」であったことから、当時何らか } \\
\text { の形で用水があったものと初期には米、小麦、菜種などを生産 }\end{array}$ & 昜など農家の風情が残る。野間神社前は緑 \\
\hline 17 & 嗵俣用水 & 不明 & $3.7 \mathrm{~km}$ & 市街 & $\begin{array}{l}\text { 元は自然の川に近いものから次第に用水として整備されたと推察され、広範囲の灌溉 } \\
\text { に用いられた。藩政期には木曳川同様水上輸送路としても用いられた。 } \\
\end{array}$ & $\begin{array}{l}\text { 長田菅原神社では樹木と潤いのある景観。途中から道路の } \\
\text { 側に治って流れ、水田を潤す。 }\end{array}$ \\
\hline 18 & 大桑用水 & 明 & $4.5 \mathrm{~km}$ & $\begin{array}{l}\text { 市街+ } \\
\text { 調整 }\end{array}$ & $\begin{array}{l}\text { れた平安期以前より流れていたと伝わる。辰 } \\
\text { 現在の流れは藩政时以降にできたと考え }\end{array}$ & $\begin{array}{l}\text { 田園風景の中を、昔ながらの素掘りのままで流れ、洗い場 } \\
\text { や隧道坑口も見られる。 }\end{array}$ \\
\hline 19 & 雀谷川 & & $2.5 \mathrm{~km}$ & 市街 & $\begin{array}{l}\text { の絵図に描かれており、農業用水として泉野一帯を潤した。洪水のたびに長坂 } \\
\text { の水田が沈んだとされる。 } \\
\end{array}$ & $\begin{array}{l}\text { 竹林等の緑と調和した景観を形成。雀橋は明治期に架けら } \\
\text { れたレンガ仕上げアーチ姿を残す。。 }\end{array}$ \\
\hline 20 & 沼田川 & & $1.0 \mathrm{~km}$ & 市街 & $\begin{array}{l}\text { この地にあった沼地を水源として泉用水に至るまでの自然河川であったと想定され、 } \\
\text { 都市排水機能を担っていた。 }\end{array}$ & $\begin{array}{l}\text { 住宅地を流れ、昔ながらの石積みを残す。流水はないが、 } \\
\text { 雨水排水路として機能を果たす。 }\end{array}$ \\
\hline 21 & 河原市用水 & & $6.9 \mathrm{~km}$ & 調整 & $\begin{array}{l}\text { 取水口が河原市領にあったた毎年水不足に陥っていた岸川下流の水を補うためにつく } \\
\text { れた。村役の橋久左衛門の働きが大きかった。 }\end{array}$ & $\begin{array}{l}\text { 波自加弥神社で水道祭が毎年行われている。上流部ではホ } \\
\text { タルやドジョウなどが生息。 }\end{array}$ \\
\hline
\end{tabular}

※辰已用水の下流部は西外・内惣構堀、鞍月用水の一部は西外惣構堀、源太郎川は一部東外惣構堀を含み、九人橋川は東内惣構堀、母衣町川は西内惣構堀を指す。

また、「区域区分」は各用水の流路の両岸の区分区域を指し、市街化区域を「市街」、市街化調整区域を「調整」と記した。 
て即地的に決定された用水の保全基準をまとめる。 3 章では, 上 記の用水の保全基準を決定した金沢市用水保全審議会の審議内容 を, 議事録の分析により明らかにする。このことから, 用水の保 全基準を決定する際に論点となっていた検討事項を抽出する。4 章では, 金沢市の用水保全の 3 つの関係部署への聞き取り調査か ら, 金沢市による保全基準に従った用水の整備, 維持管理, 活用 の状況をまとめる。そして 5 章で総合考察を行い, 審議会の議論 が用水保全基準や整備事業に及ぼした影響を考察し, 用水保全条 例の運用と今後の課題を考察する。

\section{2. 金沢市による用水保全の枠組みと保全基準}

\section{（1）金沢市の用水とその特徵}

金沢市には, 2019 年時点で, 名称がついている用水が 55 存在 している。そしてこのうち 21 の用水が金沢市によって保全用水 に指定されている（図-1)。表- 2 は, 金沢市の 21 の保全用水 の成り立ちと現在の利用を, 金沢市が発行する資料 ${ }^{17)}$ を参考に まとめたものである。金沢市の用水のほとんどは，元々は農業用 の灌溉を目的としてつくられたものであるが，市内の中心部を流 れる辰巳用水などは金沢城下の兼六園への通水や金沢城の防衛も 用水開削の目的であったといわれている。また, 大野庄用水は, 武家屋敷の内部に用水が貫流しており, 曲水庭園という文化的利 用を行っている。この他にも, 灌溉の利用に加えて, 染め物の色 落としや, 硝煙製造のための小水力発電, 市民による洗濯や野菜 の冷却などが行われていた。現在の用水の利用は, 兼六園や武家 屋敷などへの通水は継続されているが，それらは観光利用や文化 保全としての意味合いが強い。また, 近年は農業用としての用水 利用が減少する一方で, 都市のやすらぎや景観創出のための活用 が増加している。

保全用水の延長距離を見てみると, $3 \mathrm{~km}$ 以下の小規模の用水 が 8 本, $3 \mathrm{~km} \sim 10 \mathrm{~km}$ の中規模の用水が 9 本, $10 \mathrm{~km}$ 以上の大規 模な用水が 4 本ある。また, 用水自体が市街化区域のみを流れる 用水が 12 本，市街化調整区域のみを流れる用水が 2 本あり， 7 本の用水は市街化区域と市街化区域外にまたがって流れている。 このように金沢市内の用水は, その歴史的背景だけでなく, 現在 の用水沿いの都市開発状況や用水の延長距離なども多様であり, 用水の保全のために一律の規制を行うのが難しい状況にある。

\section{（2）金沢市による用水保全の政策の枠組み}

金沢市の地域性を反映させた景観政策の端緒となったものが， 1968 年の「金沢市伝統環境保存条例」である ${ }^{18)}$ 。これは,「古都 保存法（1966 年)」の対象外となった金沢市が，市内の歴史的環 境と自然環境の保全を独自に検討したものであり，自然資源や歴 史的建築と一体となった市民の環境を守っていくことが目標に掲 げられている。金沢市は，この景観保全に向けて斜面緑地や夜間 景観などの各項目に関して自主条例を順次制定し, 本研究で対象 とする用水景観の保全・活用に関して, 1996 年に「金沢市用水 保全条例」を制定した。
金沢市による用水への言及は，上記の条例や規制だけではなく， 現在の金沢市の都市計画の中にも複数みられる (表- 3$)^{19)}$ 。例 えば, 都市計画マスタープラン（金沢市，2019）の中では, 第 3 章の都市づくり方針のなかで, 交通施設等整備, 公園緑地整備, 都市環境形成，安全安心な都市づくりのために用水を活用すると いう趣旨の記述がある。また，金沢市景観計画（金沢市，2009） では，文化的景観として「旧街道・往還や幹道・枝道等の街路網， 用水・惣構跡など，今に残る近世の都市構造の保全・継承を念頭 においた景観まちづくり，公共空間の整備」を行うと明記されて おり，用水や惣構跡が文化資源の一つとされている。このように， 用水は市内全域を貫流し, その活用が防災, コミュニティ形成, 文化保全, 景観形成など多岐に渡る。このことから, 複数の都市 計画の中で用水が言及される状況にあり，様々な分野の都市整備 に同時に貢献していくために, 用水の多面的な利用やステークホ ルダーを調整することが課題となっている。

\section{（3）金沢市用水保全条例とは}

ここでは，金沢市内の用水の保全・活用に対して中心的な役割 を果たす金沢市用水保全条例の内容を説明する。金沢市用水保全 条例の第 1 条では，本条例の目的が明示されており，「藩政時代 から金沢のまちを網の目のように流れ，四季折々の風景を映し出 し，市民生活にさまざまな恵みをもたらしてきた用水を，市民と ともに保全することにより，潤いとやすらぎにあふれる本市固有 の用水環境をはぐくみ，貴重な財産として後代に継承することを 目的とする」と述べられている。そして，第 5 条では，後述する 金沢市用水保全審議会との協議の上で，市長が「特に保全を必要 とする用水」を「保全用水」として指定できることが定められて いる。

第 6 条では，保全用水に対して策定される用水保全基準の事項 が記述されている。この事項は，(1）用水の景観，（2）用水の開 渠化，（3）清流の確保，（4）用水の利用，（5）その他，の 5 つで あり, 個別の用水保全基準の策定に当たっては, 金沢市が告示を しなければならないとされている。また，第 7 条では，届出が必 要な行為として, 保全用水内における橋りょうやその他の工作物 の設置と変更, 堤防・護岸・川床の工事などが明記されている。 この他に, 保全用水に接する土地においても, 建築物やその他の 工作物の築造や改変，木竹の伐採に際しては，届出が必要となる。 このように金沢市は，保全用水と保全基準の策定を通じて，基準 に沿った用水の整備と運用を通じた, 市内の用水保全を主に行っ ている。な打本条例は, 用水やその周辺環境の改変に対する届出 を義務付け，場合によっては指導，勧告を行うものであり，法的 拘束力があるものではない。

\section{（4）金沢市が定める個別の用水の保全基準}

上記の保全方針のもとで，後述する金沢市用水審議会を経て， 保全用水の指定や，用水ごとの保全基準が決定される。表一 4 は, 保全用水の一つである鞍月用水の保全基準を「用水保全基準及び 用水保全要綱」(金沢市) ${ }^{20)}$ から転載したものである。表 -4 か

\section{表 -3 金沢市の都市計画の中での用水への言及}

\begin{tabular}{|c|c|c|}
\hline 計画名 & $\begin{array}{l}\text { 策定 (修 } \\
\text { 正) 年度 }\end{array}$ & 用水の位置づけ・用水に関する記述 \\
\hline 金沢市都市計画マスタープラン & 2019年 & 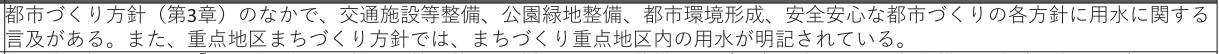 \\
\hline 金沢市景観計画 & 2009年 & 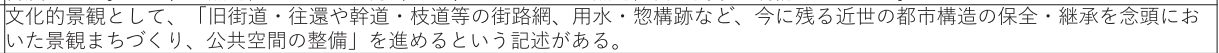 \\
\hline 金沢市歴史的風致維持向上計画 & 2017年 & $\begin{array}{l}\text { 「本市の貴重な歴史遺産である用水を保全していくうえで、今後も保全基準や保全要綱に基づき、さ地改良区・地域と連携して適切な } \\
\text { 維持管理を図っていく」(P180)とされており、コミュニティ空間としての活用などか明記されている。 }\end{array}$ \\
\hline 金沢市緑のまちづくり計画 & 2019年 & 「緑の資産」のうち「歴史文化の緑」(庭園・用水など)として用水を位置づけて水と緑のネットワークを形成することを計画している \\
\hline 金沢市地域防災計画 & 2013年 & 火災延焼予測のための用水等の資料収集や、市街地の大雨時の排水機能のために用水を活用するという言及がある \\
\hline 金沢市中心市街地活性化基本計画 & 2017年 & $\begin{array}{l}\text { 「緑あふれれる都市づくり事業(水と緑のまちなか交流プラン」という事業を実施し「河川、用水、公園などや公益施設民有地の緑化に } \\
\text { より、水・緑資源の連続性を確保」するとれている。 }\end{array}$ \\
\hline 第 2 次金沢交通戦略 & 2016年 & 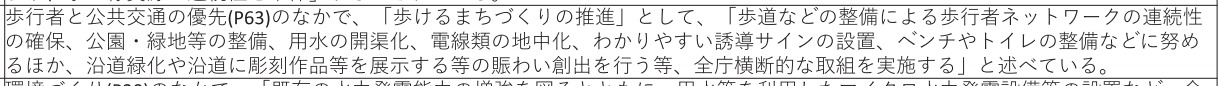 \\
\hline 世界の「交流拠点都市金沢」を目指して & 2013年 & 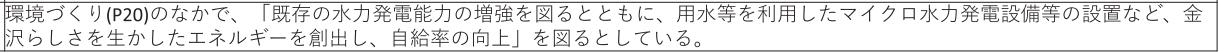 \\
\hline
\end{tabular}


表 -4 鞍月用水の保全基準の記述内容（「用水保全基準及び用水保全要綱」（金沢市）より転載）

\begin{tabular}{|c|c|c|c|c|c|c|c|c|}
\hline \multirow[b]{2}{*}{ 区間 } & 用水保全基準 & \multicolumn{7}{|c|}{ 用水保全基準要網（区間別特記事項） } \\
\hline & 鞍月用水 （延長4,295m） & $\begin{array}{l}\text { (1)城南 } \\
\text { 区間 }\end{array}$ & (2)菊川区間 & 3)幸町区間 & $\begin{array}{l}\text { (4)鱗町. 油車 - 茨 } \\
\text { 木町·里見町区間 }\end{array}$ & $\begin{array}{l}\text { (5)柿木畠・片 } \\
\text { 町・香林坊区間 }\end{array}$ & 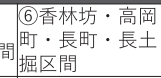 & $\begin{array}{l}\text { (7)芳斉・昭和町・中 } \\
\text { 橋町区間 }\end{array}$ \\
\hline 基本事項 & 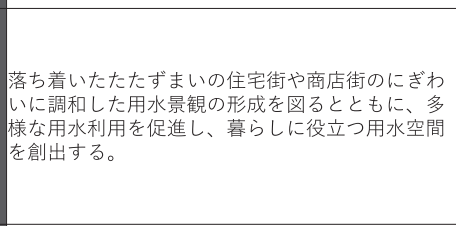 & $\begin{array}{l}\mid \text { 道路敷 } \\
\text { 暗渠区 } \\
\text { 闇ば } \\
\text { 基本的 } \\
\text { 通行 } \\
\text { 通りと } \\
\text { する。 }\end{array}$ & 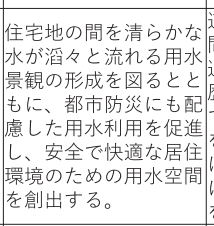 & 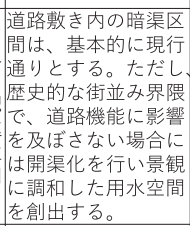 & 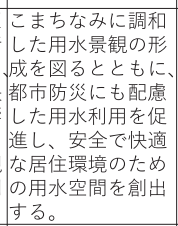 & 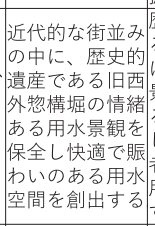 & 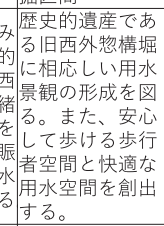 & 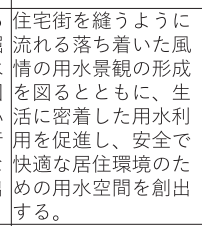 \\
\hline $\begin{array}{l}\text { 用水の景 } \\
\text { 観に閏す } \\
\text { る事項 }\end{array}$ & 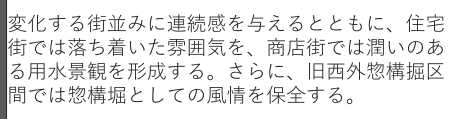 & & & & 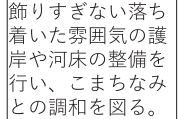 & & & $\begin{array}{l}\text { 飾りすぎない落ち着 } \\
\text { いた霜围気の用水景 } \\
\text { 観を形成する。 }\end{array}$ \\
\hline $\begin{array}{l}\text { 閶皆化の } \\
\text { 远に開 } \\
\text { する事項 }\end{array}$ & $\begin{array}{l}\text { 必要以上に幅の広い私有橋の撤去または狭小化を } \\
\text { るり、通行以外の目的には使用しないように努め } \\
\text { る. }\end{array}$ & & 私有橋は架設しない。 & & $\begin{array}{l}\text { 特に私有橋の荚小 } \\
\text { 化を積检的に推進 } \\
\text { する。。 }\end{array}$ & 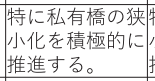 & $\begin{array}{l}\text { 灰特に私有橋の狭 } \\
\text { :小化をを積極的に } \\
\text { 推進する。 }\end{array}$ & $\begin{array}{l}\text { 特に私有橋の狭小化 } \\
\text { を積極的に推進する。 }\end{array}$ \\
\hline $\begin{array}{l}\text { 清流の確 } \\
\text { 保に潤す } \\
\text { る事頃 }\end{array}$ & 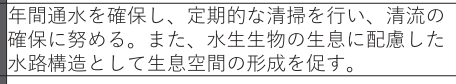 & & & & & & & \\
\hline $\begin{array}{l}\text { 用水の利 } \\
\text { 用に閏す } \\
\text { る事項 }\end{array}$ & 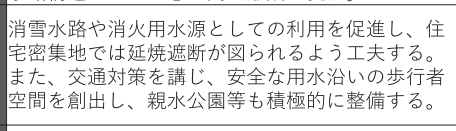 & & $\begin{array}{l}\mid \text { 特に防火用水と消霞水 } \\
\text { 洛としての利用を促進 } \\
\text { する。 }\end{array}$ & & \begin{tabular}{|l|l|} 
広見沿いでは、積 \\
的に階段を設け \\
る。
\end{tabular} & 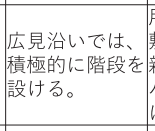 & 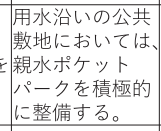 & $\begin{array}{l}\text { 防火用水と消雪水路 } \\
\text { としての利用を促進 } \\
\text { する。 }\end{array}$ \\
\hline 他 & & & & & & & & \\
\hline
\end{tabular}

表 -5 全 21 の保全用水の保全基準・要綱の記述内容

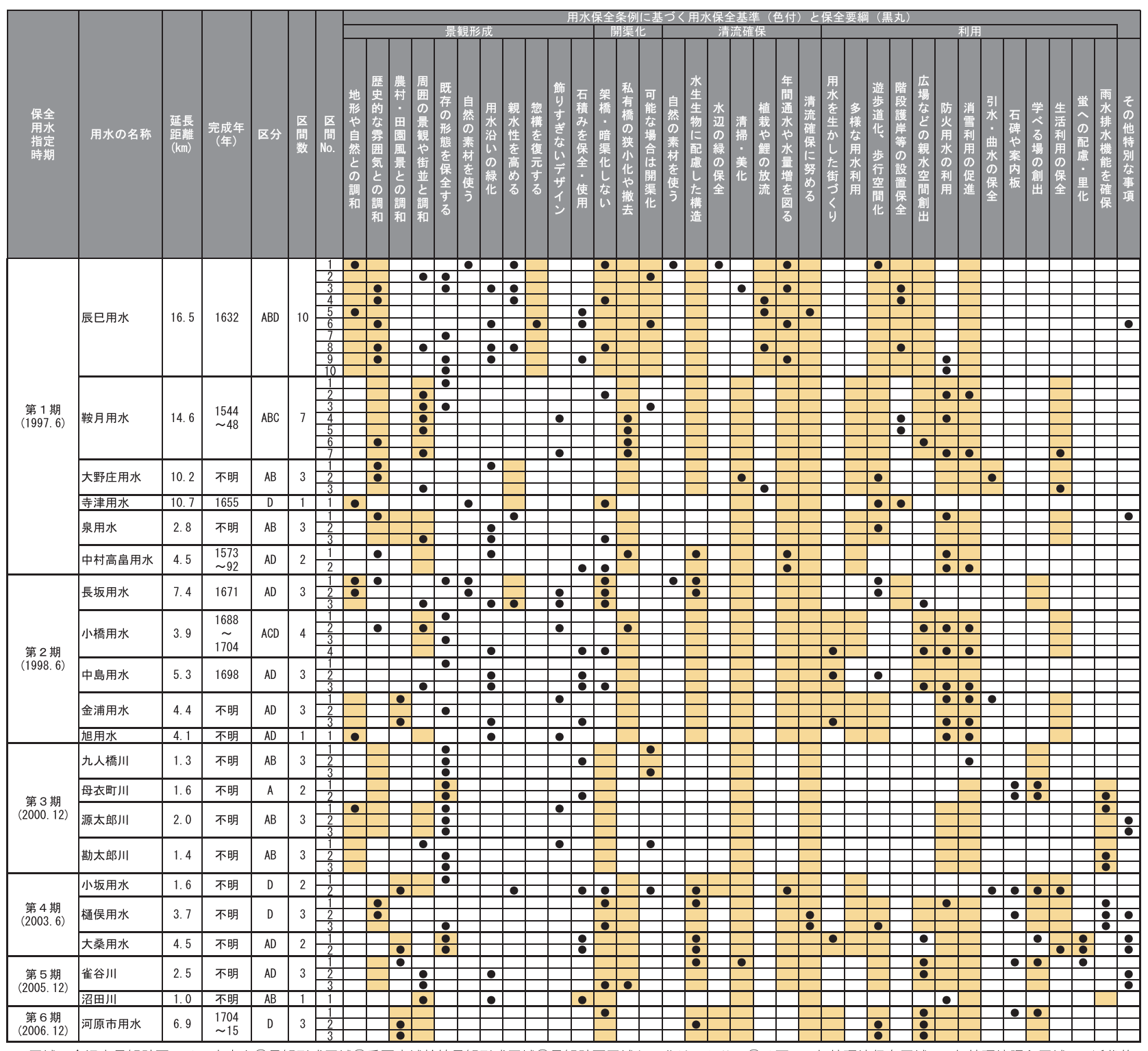

※区域：金沢市景観計画では、市内を(1)景観形成区域(2)重要広域幹線景観形成区域(3)景観計画区域とに分けており、(1)は更にA:伝統環境保存区域、B:伝統環境調和区域、C:近代的 都市景観創出区域に分けられている。本表ではA,B,C,及びそれ以外の(2)(3)をDとし、各用水が貫流する景観計画上の区域を示した。 
らも分かるように, 用水全体の保全方針を示す「保全基準」に加 えて, 用水の区間ごとの保全方針を示す「保全基準要綱（以下， 「要綱」とする)」が明示されている。なお，この区間の分割は, 周辺の開発状況や文化的背景から決定されている。

用水の保全基準之要綱は, 基本事項に加えて上述した 5 つの項目 (用水景観, 開渠化, 清流の確保, 用水利用, その他) に従って 言及される。例えば, 鞍月用水の「(2)菊川区間」では, 住宅地で あることを考慮して, 都市防災の向上や安全で快適な居住環境の 創出が目的とされ，新たに私有橋の架設をしないことや，防火・ 消雪としての用水利用を確保することが記述されている。一方, 飲食店や小売店が多数存在する「(5)柿木畠・片町・香林坊区間」 では，快適でにぎわいのある用水景観が重視されている。ここで は，店舗などにつながる私有橋を狭小化していく一方で，市民が 集まる広見などにおいて, 用水の水面まで接近できるような階段 などを設置する要綱が明記されている。このように, 周辺の開発 状況や市民の利用状況に応じて, 区間ごとの保全の方針や要綱は 異なっており，この結果として，それぞれの場所に固有の用水景 観が保持されることが目指されている。

表一 5 は，全 21 の保全用水の保全基準の傾向を把握するために, 5 つの方針ごとにすべての保全基準と区間ごとの要綱の記述内容 をまとめたものである。表－5の作成にあたっては，筆者によっ て,「用水保全基準及び用水保全要綱（金沢市）」に記載されてい る保全基準と要綱の記述内容を 35 項目に分類し, 用水全体の方 針を示す保全基準に該当項目がある場合は黄色, 区間ごとの方針 を示す要綱に該当項目がある場合は○をつけている。

まず, 用水の区間ごとの要綱の記載（表－５のの部分）に着目 する。全 21 の保全用水は総計で 65 の区間に分けられており, 区 間数が最も多いのが辰巳用水の 10 区間, 少ないのが寺津用水, 旭用水，沼田川の 1 区間であった。要綱の記載内容で多いのが, 「既存の形態を保全する」(26区間),「架橋・暗渠化しない」(17 区間)，「周囲の景観や街並みに調和」(16 区間)，「防火用水の利 用」(16 区間), 「用水沿いの緑化」(16 区間) である。逆に $1 つ$ の区間でしか要綱に記述がなかった「その他特別な事項」は「䊍 構を復元する」「工作物の撤去」「再開発に合わせて開渠化」「窯場」 「アーチ橋の保全」「住民の理解と協力を得る」に関する記述であっ た。

この区間ごとの要綱の記載量には大きな差がある。例えば, 要 綱に「既存の形態を保全する」という記載しかない区間が 7 区間 ある一方で, 小坂用水 2 区間の要綱には, 「農村・田園風景との 調和」「可能な場合は開渠化」「年間通水や水量増を図る」「引水・ 曲水の保全」等の 11 項目に関する言及がある。このように 7 項 目以上の要綱の記載があるのは, 全部で 11 区間存在している。

また, 特定の内容が要綱の中に同時に記載されるという傾向も 存在する。例えば, 「私有橋の狭小化・撤去」という記述が 7 区 間の要綱で存在しているが，このうち 5 区間で「周囲の景観や街 並みと調和」，4区間で「防火用水の利用」に関する記述も行わ れている。この他にも,「遊歩道化・歩行空間化」を要綱に含め る場合（10区間）には，5区間で「架橋・暗渠化しない」，4区 間で「自然の素材を使う」という記述が要綱に含まれていた。

次に, 用水単位の保全基準の記述内容（表－５の黄色部分）に 着目する。まず，景観形成に関して，「歴史的雾囲気との調和」 の記述がある 9 用水のうち 8 用水が, 市内中心部の「A 伝統環 境保存区域」を貫流していた。一方で，保全基準に「農村・田園 風景との調和」の記載がある 5 用水のうち 4 用水が「D 景観形成 区域外」を貫流している。開渠化に関する保全基準は,「私有橋 の狭小化や撤去」と「架橋・暗渠化しない」という二つに大別さ れるが，「架橋・暗渠化しない」という明確な方針が記載されて いるものは，ほとんどが第 2 次以降に保全指定された用水であっ
た（ 9 用水のうち 8 用水)。また, 全ての用水の保全基準で「清 流確保」が，20の用水で「清掃・美化」の記述が見られ，それ に伴い多くの用水で「年間通水や水量増」「水生生物に配慮した 構造」についての記述が見られる。用水利用に関しては, 「遊歩道・ 歩行空間化」「防火利用の確保」「消雪利用の促進」という利用が 促進される傾向にあり，特に第 3 次以降の保全用水では，「学べ る場の創出」や「雨水排水機能の確保」といった新たな利用が想 定されている。

このように, 用水の立地や保全指定時期によって保全基準や要 綱に一定の傾向が認められる。しかし, 表一 5 からも明らかなよ うに, 用水保全基準は用水の現況や利用状況等によって大きく異 なっており，同じ保全基準を持つ用水は一つとして存在しない。 続く 3 章では，このような用水の保全基準の内容をどのような審 議から決定したのかを，審議会の議事録をもとに分析する。

\section{3 . 金沢市用水保全審議会による保全基準策定に至る審議事項}

\section{（1）金沢市用水保全審議会とは}

用水の整備方針を個別に審議し，決定しているのが，金沢市用 水保全審議会（以下，「審議会」とする）である。金沢市用水保 全条例の第 15 条によれば, 審議会とは「条例に規定する事項そ の他の事項について市長の諮問に応ずるほか，用水の保全に必要 な事項について市長に建議する」ことを行う組織とされている。 また, 同条例第 16 条は, 審議会の委員は「知識経験を有するもの, 関係行政機関の職員及び本市の職員の内から市長が委嘱し，また は任命する」と定め, 委員は任期 2 年の 20 人以内で構成してい る ${ }^{21)}$ 。

このように金沢市では有識者によって用水の保全が検討され， その審議の結果が保全用水の決定や個別の用水の保全基準の内容 に反映される。なお，1996 年からこれまでに全 28 回の審議会が 行われている。

\section{（2）金沢市用水保全審議会の審議内容の分析}

ここでは, 審議会で議論された内容を, 主な議題の推移, 多面 的利用の調整, 利用と管理の調整, 周辺環境との関係性に着目し て分析する。なお，対象とする審議会の議事録は，これまでに開 催された 1996 年から 2016 年までの全 28 回とする。分析に当たっ ては, 用水保全のための保全方針, 整備方法, 利用, 管理に関わ る言説を全て抜き出し，各言説を 1 つの意見となるまで分割した うえで, 同様の意見をまとめてグループ化を行い「多面的な利用 の調整」「文化的背景や立地」「利用之管理の調整」に関する表一 6 〜 を作成している ${ }^{22)}$ 。

1) 審議会に打ける議題の推移

図-2 は, 第 1 回から第 28 回までの審議会の議題の推移を時 系列にまとめたものである。審議会は, 保全用水の指定を審議対 象とする用水ごとに 6 次に分けて行なわれている。第 1 次指定で は, 辰巳用水, 鞍月用水, 大野庄用水, 寺津用水, 泉用水, 中村 高畠用水という, 旧市街地を流れる歴史的価值が高く, 市民から の認知度や親しみが強い用水の保全指定が行われた。その後, 第 3 次指定では点的に残る歴史的価值の高い景観の保全審議が行わ れ，第 4 次指定では将来の開発が想定される地区の用水を先取り で保全すること, 第 6 次指定では郊外部の農村景観が残る地区の 用水の保全の検討が行われた。

第 1 回の審議会で，当時の市長の山出氏によってまず述べられ たことが，用水保全を通じて金沢特有のコミュニティ空間を取り 戻し，都市のコミュニティ意識を向上するという方針であった 23)。このこともあり, 以降の審議の中では, 歴史的価值のある用 水をただ残すのではなく，その価值をどう市民に伝えていくか， どのように市民と用水の関わりを生み出してコミュニティ活動に 発展させていくかということが検討されている。 


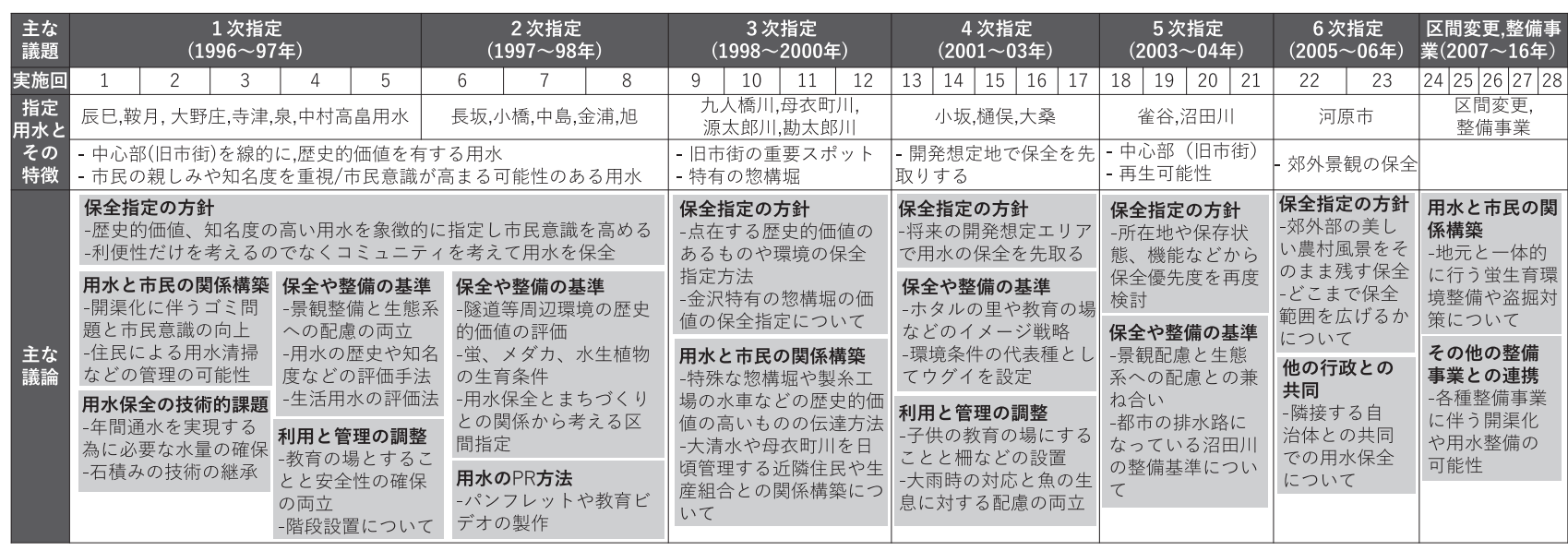

図－２＼cjkstart金沢市用水審議会の審議事項の推移

\begin{tabular}{|c|c|c|}
\hline 課題 & 用水の多面的利用とその調整 & 解決手段や現状 \\
\hline $\begin{array}{l}\text { 都市的な利用 } \\
\text { と農業利用の } \\
\text { 用水の流速の } \\
\text { 調整(全て) }\end{array}$ & $\begin{array}{l}\text { (景観/市民)散策路沿いでは流速は早くない方が良い } \\
\text { (環境)生物の生息環境を考えると早くない流速が良い } \\
\text { (農業)農地に効率的に水を供給するには速い流速が良い }\end{array}$ & $\begin{array}{l}\text { 石の積み方を工夫し } \\
\text { 部分的に流速を下げ } \\
\text { るなどして対応した }\end{array}$ \\
\hline $\begin{array}{l}\text { 用水沿いの歩 } \\
\text { 道の䈻装の有 } \\
\text { 無(河原市) } \\
\text { 用水沿いのラ } \\
\text { イトアップと } \\
\text { 蛍の生育環境 } \\
\text { の維持(河原市) }\end{array}$ & 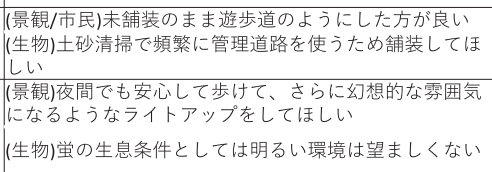 & $\begin{array}{l}\text { 管理の頻度を考慮し } \\
\text { |て歩道の舗装を行っ } \\
\text { た } \\
\text { 蛍の生息地に部分的 } \\
\text { に遮光板を設置して } \\
\text { まます明かりを防ぐ } \\
\text { ようにしてはどうか }\end{array}$ \\
\hline $\begin{array}{l}\text { 景観維持と生 } \\
\text { の生育環境 } \\
\text { の維持(雀谷) }\end{array}$ & $\begin{array}{l}\text { (景観)景観を綺麗に保つためにも堆積した土砂を定期的 } \\
\text { 清掃したほうがいい } \\
\text { (生物)堆積物をなくすと蛍が生息できなくなってしまう }\end{array}$ & $\begin{array}{l}\text { 専門家に助言をもら } \\
\text { いながら適切な程度 } \\
\text { 少清掃を実施するここ } \\
\text { とにした }\end{array}$ \\
\hline $\begin{array}{l}\text { 内水管理と生 } \\
\text { 物の生息環境 } \\
\text { の維持 } \\
\text { (1次指定) }\end{array}$ & $\begin{array}{l}\text { (防災)増水を避けるために雨水排水機能を持たせる必要 } \\
\text { がある } \\
\text { (生物)大雨時に水の流れを止めてしまうと、魚がいられ } \\
\text { る場所かななってうう }\end{array}$ & $\begin{array}{l}\text { 川床に䆶みを定期的 } \\
\text { に設し置し量不足時 } \\
\text { にも一時的に魚が退 } \\
\text { 避できるようにした } \\
\text { いくつかの場所で魚 } \\
\text { 道を確保した }\end{array}$ \\
\hline $\begin{array}{l}\text { 都市部で年間 } \\
\text { 通水を可能に } \\
\text { するための水 } \\
\text { システムの整 } \\
\text { システ備(辰巳) }\end{array}$ & 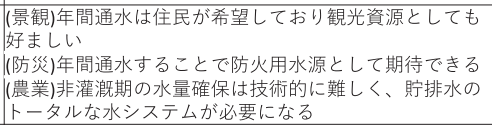 & $\begin{array}{l}\text { 辰巳ダムの竣エによ } \\
\text { り水量確保の問題が } \\
\text { 無くなり年䦗通水が } \\
\text { 可能となっなた }\end{array}$ \\
\hline $\begin{array}{l}\text { 用水沿いの慣 } \\
\text { 行的な土地利 } \\
\text { 用の制限(沼田) }\end{array}$ & $\begin{array}{l}\text { (生活)かつて管理道として利用されていた土地がいつの } \\
\text { 間にか隣接地に組み込まれており、用水上に建造物があ } \\
\text { る場所がる } \\
\text { (景観)開渠部分の補修や景観上の配慮を行った方がいい }\end{array}$ & $\begin{array}{l}\text { 補償なども含めて長 } \\
\text { 期な交渉を行う方 } \\
\text { 針を立てた }\end{array}$ \\
\hline
\end{tabular}

審議会で議論された主な内容は, 保全を検討する用水ごとの「保 全指定の方針」「保全や整備の基準」「用水之市民の関係構築」で あり,この議論を行うにあたって, 個別の用水の歴史的価值や現 在の利用・管理の状況などが話し合われている。具体的には, 例 えば, 第 1 次指定の用水については「惣構堀は特徵的な歴史文化 を持つ, 他の用水と一味違うもの」（第 3 回審議会）なので保全 すべきという意見が, 第 4 次指定以降では, 「地域の自然を活か すことが必要ですね。あまりいじりすぎない方が良い」（第 22 回 審議会）などの意見がある。また, このように, 審議会で対象と する用水が，回を追うごとに都市部から郊外部へと推移していく ことで, 多面的な利用の調整や管理に関する様々な論点が議論さ れている。

2 ) 用水の多面的な利用の調整に関する議論

表 -6 は, 全 28 回の審議会の中で, 用水の多面的な利用の調 整に関して議論された事項をまとめたものである。審議会では, 用水を中心とした都市コミュニティの創造のために, 都市におけ る用水の積極的な活用やそのための整備手法がいくつも提示され た。そして, それまで中心的であった農業利用との間や, 新たな 利用同士の調整を行うための議論が行われている。

農業利用との調整に関しては, 例えば, 景観, 市民利用, 環境 の観点から用水の流速を抑えることが提案されたが, 効率的な農 業利用を考える立場から流速を抑えることに難色が示され, 最終

\section{表 -7 用水の利用と管理の調整に関する議論}

\begin{tabular}{|c|c|}
\hline 利用や管理上の要請 & 対応状況 \\
\hline $\begin{array}{l}\text { (利用）開渠化し散策路を整備する } \\
\text { (管理) ゴミ投金による下流部の農家への支障 }\end{array}$ & $\begin{array}{l}\text { 市民への教育や啓蒙をすすめ } \\
\text { ていく(1 次) }\end{array}$ \\
\hline $\begin{array}{l}\text { (利用) 川床を石積などの伝統的な方法で修景したい } \\
\text { (管理) 高齢者が多い住宅密集地域では雪の始末を優先した } \\
\text { うがいい } \\
\text { (管理) 雨水排水機能の負担軽減する必要がある }\end{array}$ & $\begin{array}{l}\text { 職人不足などもあり、石の䏚 } \\
\text { 間をコンクリートにするなど } \\
\text { の現代的な工法にせざるを得 } \\
\text { |い(1次) }\end{array}$ \\
\hline $\begin{array}{l}\text { (利用) 開渠化をすすめて親水性を高める } \\
\text { (管理に困っている } \text { 土砂崩落の危険がある地域のた管理 }\end{array}$ & $\begin{array}{l}\text { 安全性を考慮して無理な開渠 } \\
\text { 化をすすめいいようにする } \\
\text { (大桑) }\end{array}$ \\
\hline $\begin{array}{l}\text { (利用) 階段護岸などの親水性を高める } \\
\text { (利用) 用水や生き物に触れ合える子供の学習の場をつくる } \\
\text { (管理) 柵などがなく階段状になっていると人間や動物が転落 } \\
\text { する危険がある }\end{array}$ & $\begin{array}{l}\text { 階段護岸は整備するが柵を立 } \\
\text { ててて施錠することとした(鞍 } \\
\text { 月) }\end{array}$ \\
\hline $\begin{array}{l}\text { (利用) 大清水は数少ない現存する湧水のためその重要性を } \\
\text { PRしたい } \\
\text { (管理) 地元の人々の手でひっそりと守られており、観光客が } \\
\text { たくさん集まることは望ましくない }\end{array}$ & $\begin{array}{l}\text { スポット的な保全指定はしな } \\
\text { いで源太郎川の一部として保 } \\
\text { 恮指定することにした(勘太 } \\
\text { 郎) }\end{array}$ \\
\hline $\begin{array}{l}\text { (利用) 蛍の里として地元と一体的に環境を保全したい } \\
\text { (管理) 冬季のカワニナの盗掘への対策が必要 }\end{array}$ & $\begin{array}{l}\text { 保全と盗掘対策を同時に進め } \\
\text { ることとした(大桑) }\end{array}$ \\
\hline
\end{tabular}

\section{表 -8 用水の文化背景や立地場所が整備方針に与えた影響}

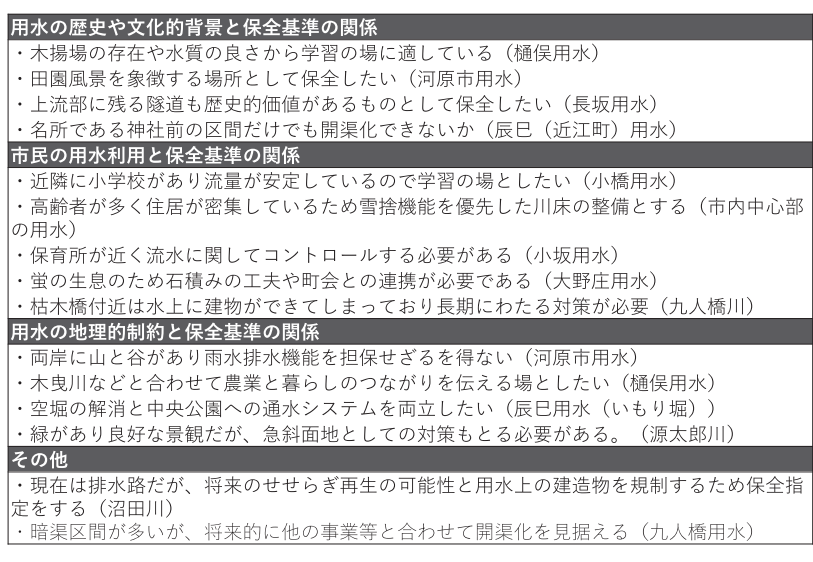

的に「どうしたらホタルが出るかということを検討した結果, こ ういった流速を抑えるような石を並べるといった整備を行いまし た」(第 27 回審議会) とあるように, 用水の川床のデザインを工 夫して局所的に流速を調整することが決定されている。また，用 水沿いの歩道に関しては, 景観の観点から未舗装のデザインが望 まれたが，農家の利用の観点から歩道を舗装することが推奨され， 最終的に歩道の舗装が決定した。

一方，新たな利用間の調整は，生物の生息環境の創出との間に 生じるものが多い。例えば，「昼の整備だけではなく，夜の街灯 整備 (屯必要)」(第 23 回審議会) などのように, 夜間景観や防 災を考えて用水沿いのライトアップを提案する意見があったが， 蛍の生育環境を考える立場から過度な電飾の使用を行わないほう 
が良いという指摘がなされ，蛍が生息する場所に斜光板などを部 分的に用いる整備方法が検討された。この他には，生物の生息環 境の創出と景観や内水整備とを調整するために, 魚道の確保や清 掃の頻度に関する議論が行われている。このように, 多面的利用 の調整に関する議論の特徵は, 何かの用水利用を優先するのでは なく，打互いに譲歩して同時に複数の用水利用を実現することで ありこのために創造的な解決策がいくつも検討されている。

また，上記の新たな用水利用の創出のために，年間を通じて都 市部で用水利用を行うための水量確保に関する議論も行われてい る。この議論は, 辰巳ダムが竣工したため解決することができた が，都市の用水利用を新たに考える場合には，新たな用水の取水 と排水の環境を整備することが大前提となる。

3 ) 用水の利用と管理の調整に関する議論

表一 7 は, 用水の新たな利用に対する管理方法や管理負担に関 する議論をまとめたものである。審議会ではこれまでに, 用水利 用だけでなく, 管理の方法やリスクを考慮して, その整備方法や 整備に付随して行うソフト事業の実施が議論されてきた。例えば, 用水の開渠化の推進に対しては，ゴミ投棄をはじめとした「下流 に位置する農家への影響（第 1 回審議会）を懸念する意見があり， この課題に対しては, 開渠化の方針を変更するのではなく, 市民 への用水保全に関する教育や啓蒙といったソフト事業の実施によ る解決策が話し合われている。また，景観だけを考えて用水の川 床を石積みや伝統的な工法のみで修景していくのではなく, 消雪 や雨水排水といった水管理の負担を考えて, 川床の一部をコンク リートにして整備していくことなどが提案されている。この他 には, 土砂崩落の危険がある場所では, 無理に開渠化を進めるの ではなく安全性を最大限に考慮するなどの議論も行われた。また, 地域住民によって大切に管理されている用水に観光利用が急増し ないように，当該用水の保全範囲や周知方法が検討されている。

このように，新たな用水利用のための整備を行うと，既存の管 理方法を変更することや，新たな管理負担が生じる可能性がある。 このため, 用水の整備前から市民間のトラブルを想定して, 保全 基準を定めていくことが重要になる。一方で, 審議会では, 新た な利用から生じる管理負担を誰が行うかという点はあまり議論さ れていなかった。「惣構を整備した後の管理は市で行うのですか」 「広場の方は地元ボランティア等による清掃などは考えていない のですか」(第 27 回審議会) などの発言はあったものの, 都市の 用水利用により生まれる新たな受益者による管理への参加はこれ までにほとんど議題にあがっていない。今後の用水の利用によっ て受益者に偏りが生じていく場合には，管理負担の調整に関する 議論も行うことが必要だと推察される。

表 -9 保全基準策定後に行われた用水整備事業

\begin{tabular}{|c|c|c|c|}
\hline 保全用水 & 事業名 & 期間 & 対象エリア \\
\hline \multirow{2}{*}{ 辰已用水 } & 辰已用水開渠化工事（尾山神社前） & 2008年度 & 尾山町 \\
\hline & $\begin{array}{l}\text { まちなか辰巳用水（高岡町排水路）修 } \\
\text { 景整備事業 }\end{array}$ & 2019年度～ & 安江町 \\
\hline 鞍月用水 & 鞍月用水整備事業 & $1995 \sim 04,09$ 年度 & 昭和町～片町 \\
\hline 大野庄用水 & 大野庄用水整備事業 & 2007～12年度 & 中央通町～片町 \\
\hline \multirow{2}{*}{ 寺津用水 } & 身近な水辺環境再生事業（環境省） & 1999 01年度 & 末町 \\
\hline & 水辺空間再生施設整備事業（環境省） & 2002 03年度 & " \\
\hline
\end{tabular}

表一10 金沢市による用水管理の分担

\begin{tabular}{|c|c|c|c|c|}
\hline \multirow{2}{*}{$\begin{array}{l}\text { 管理 } \\
\text { 主体 }\end{array}$} & \multicolumn{3}{|c|}{ 金沢市 } & \multirow{2}{*}{ 土地改良区 } \\
\hline & 歴史都市推進課 & 内水整備課 & 農業基盤整備課 & \\
\hline 对象 & 保全指定用水 & 主に市街化区域内 & 主に市街化調整区域内 & 所有する水門や堰 \\
\hline 内容 & $\begin{array}{l}\text { 景観保全のための } \\
\text { 維持管理 }\end{array}$ & $\begin{array}{l}\text { 水防や都市排水に関 } \\
\text { して法定外公共物と } \\
\text { しての用水管理 }\end{array}$ & $\begin{array}{l}\text { 農業用水としての維持 } \\
\text { 管理 }\end{array}$ & $\begin{array}{l}\text { 上記の日常的管理 } \\
\text { や掃除 }\end{array}$ \\
\hline
\end{tabular}

4 ）用水の文化背景や立地場所が整備方針に与えた影響

表一 8 は，用水の整備方針に影響を与えた即地的な事項や文化 的背景をまとめたものである。まず，個別の用水の歴史や文化的 背景が保全基準に影響を与えることがある。例えば，もともと木 揚場として活用されていた樋俣用水では，「総合学習の場としたい」 （第 15 回審議会）などのように，当時の用水利用を伝える場の整 備についての話し合いが行われた。また，農業利用が継続されて いる河原市用水では，現在の田園風景を伝えることを念頭に用水 の景観整備を行うことが合意されている。

また，用水沿いの居住者や土地利用が保全基準に影響を与える こともある。小橋用水沿いには小学校が立地しているが，そこで は流量も十分なこともあり, 学習の場としての用水整備が話し合 われている。また，高齢者が多数居住している区間では，景観で はなく雪捨て機能を優先した川床整備が検討されている。

最後に, 用水の地理的制約が保全基準に影響を与える事例も存 在する。例えば，郊外部を流れる河原市用水の両岸が山と谷で囲 われる部分では，用水整備に雨水排水機能を付加することが決定 された。この他には, 将来の開発行為の可能性が高い地域で, 事 前に用水の保全を行うことで環境維持を試みる事例もある。

このように，金沢市では用水の保全方針の大枠を条例で定めて はいるが，機械的に用水の保全基準を策定していくことはせず, それぞれの用水の歴史的な背景や市民の利用, 愛着などを勘案し て，個別の保全基準を策定している。そしてこの結果として，用 水ごとに独自の整備が実現し，地区固有の魅力的な用水景観を実 現していくことが目指されている。

\section{4. 現在の金沢市の用水の保全と活用のための取り組み}

本章では，金沢市の用水管理に関係する 3 つの部局へのヒアリ ング調査をもとに，金沢市が用水の保全と活用を具体的にどのよ うに進めているかを把握する。なお，ヒアリング調査は金沢市の 3 部局が同席した形で 2019 年 11 月 20 日に金沢市役所で対面実 施し, 用水保全条例の運用に関しては歴史都市推進課に, 市街化 区域の用水利用之維持管理については内水整備課に，市街化調整 区域の用水利用之維持管理に関して農業基盤整備課から回答を得 た。主な質問内容は，「保全用水の整備事業の実施の状況」「保全 用水の保全基準に従った日常的な維持管理の体制」「保全用水の 活用のための行政施策」の三点である。

（1）保全用水における整備事業の実施について

まず，用水保全条例に従って金沢市により実施されたこれまで の主な整備事業の実施状況を伺った（表－9）。これまで述へてて きたように，保全用水の指定や用水の保全基準は審議会によって

\section{表－11 金沢市の条例にみる用水の位置づけと活用}

\begin{tabular}{|c|c|c|}
\hline 分野 & 条例 & 用水の位置付けと活用 \\
\hline $\begin{array}{c}\text { 用水保 } \\
\text { 全 }\end{array}$ & 金沢市用水保全条例 & $\begin{array}{l}\text { 特に保全の必要がある用水を「保全用水」に指定。「用水 } \\
\text { 景観」「開渠化」「清流確保」「用水利用」の4方針で整備。 } \\
\text { 全用水およ゙接する土地での行為には出が必要。 }\end{array}$ \\
\hline 防災 & $\begin{array}{l}\text { 金沢市における災害 } \\
\text { に強い都市整備の推 } \\
\text { 進に関する条例 }\end{array}$ & $\begin{array}{l}\text { 第11条 市長は、災害による火災の発生時に敃ける消火及 } \\
\text { び火災の拡大の防止を図るため、河川、用水等を消火活動 } \\
\text { に活用できるよう整備するとともに、多様な消防水利の確 } \\
\text { 保に努めなければならない。 }\end{array}$ \\
\hline 景観 & $\begin{array}{l}\text { 金沢市における美し } \\
\text { い景観のまちつづくり } \\
\text { に関する条例 }\end{array}$ & 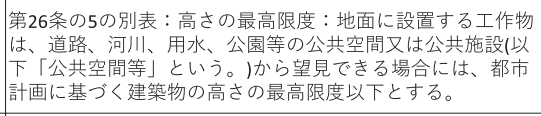 \\
\hline $\begin{array}{c}\text { 歩ける } \\
\text { まち }\end{array}$ & $\begin{array}{l}\text { 金沢市における歩け } \\
\text { るまちづくりの推進 } \\
\text { に関する条例 }\end{array}$ & $\begin{array}{l}\text { 第7条: 市長は、歩けるまちづくりを推進するため、本市固 } \\
\text { 有の自然、地形、用、水、緑地、歴史的建造物、文化施設等 } \\
\text { を生かした散策路等のうち、金沢のまちの風情と良さをを身 } \\
\text { 近に感じて歩くことができる道の経路を歩けるみち筋とし } \\
\text { て指定することができる。 }\end{array}$ \\
\hline $\begin{array}{l}\text { コミュ } \\
\text { ニティ }\end{array}$ & $\begin{array}{l}\text { 金沢市における広見 } \\
\text { 等のコミュニティ空 } \\
\text { 間の保存及び活用に } \\
\text { 関する条例 }\end{array}$ & $\begin{array}{l}\text { (1)広見 (2)寺社等の境内 (3)袋小路(4)用水(5)わき水などのコ } \\
\text { 三ュニティ空間の保存及び活用を促進し地域コミュニティ } \\
\text { の活性化に資する }\end{array}$ \\
\hline
\end{tabular}


進められるが，金沢市は限られた予算の中でこの保全基準に即し た整備事業を少しずつ進める必要があり, 整備事業が保全基準に 従って全て即時的に実施されるわけではない。このなかで, 優先 的に用水整備が実施されてきた場所が, 特に歴史的価值が高く, 市民との関わりが強いと判断される, 保全用水の第 1 次指定を受 けた, 辰巳, 鞍月, 大野庄, 寺津用水であった。また, 再開発事 業などを契機に，辰巳用水の一部整備も検討されている。

一方, 用水の開渠化や私有橋の狭小化などは地権者の合意が必 要となるため, 用水保全がなかなか進まない場所も存在している。 この他に, 道路が狭小で入り組んでいる, 土地所有者が異なるな どの物理的制約がある場所でも用水整備が進展しない事例がある 24)。なお，これまでのところ，市民から用水の開渠化や私有橋の 撤去の要望が出されたことはなく, 行政が主導で用水整備事業を 進めていかなければならない状沉にあった。

\section{（2）用水の維持管理について}

次に, 整備事業後に保全用水の景観や清流を保っていくために 行う，日常的な維持管理の状況を伺った。聞き取り調查をもとに, 金沢市の用水管理の分担の状況をまとめたものが表-10である。 これまで説明してきた保全指定用水の保全・整備事業は歴史都市 推進課が行っている。一方, 主に市街化区域内の都市排水や水防 上の管理とこれに伴う法定外公共物の維持は内水整備課が行うこ ととなっている。例えば, 豪雨などによる増水時の排水対応は内 水整備課が担当しており, 保全基準に従った整備事業とは分別さ れている。また, 主に市街化調整区域内の農業用水としての管理 は農業基盤整備課が担当している。

ただし，農業利用のための水門や堰の管理は，それぞれの用水 を利用している土地改良区（農家など）が自ら維持管理を行うこ ととなっている。このため, 農業利用を行っている用水の取水口 や堰に堆積する枯葉やゴミなどの日常的な処理は土地改良区が行 う状況にあった ${ }^{25)}$ 。

\section{（3）用水の利用について}

最後に, 保全基準策定後の用水の利用に関する事業実施の状況 を伺った。これまでの金沢市による用水の利用とその根拠となる 条例は, 表一 11 のようにまとめられる。歩けるまちづくりのた めに, 特に辰巳用水, 鞍月用水, 寺津用水において, 金沢市が遊 歩道を整備しており, 散策路としての利用を促進している。用水 の景観資源としての活用は, 用水景観の整備に加えて魚の休喤場 所やホタルの生育環境を形成するための川床の石置きなどの工夫 を行っている。これらの取り組みは, 市民によって 30 年以上行 われている用水沿いのホ夕ル観測などの, 用水を舞台とした自然 とのふれあいの機会の増加に貢献している。一方, コミュニティ 活性化に資する利用としては, 商店会などが主催する用水沿いや 広見における複数のお祭りに対する補助が市民協働課によって行 われている。また, 防災のための用水利用として, 鞍月用水や大 野庄用水の交差点付近の川床に消防車用の水を貯める場所が確保 されている。

このように，用水を整備して事業を完了するのではなく，用水 を積極的に利用して市民の豊かな生活環境を形成するための取り 組みが金沢市の事業に複数存在していた。

\section{5 . 本研究の結論と今後の課題}

\section{(1) 本研究の結論}

本研究では, 金沢市の用水保全の取り組みを対象に, 即地的に 策定された保全基準の分析，保全基準の策定時に論点となった用 水の多面的機能と管理の調整に関する議論の抽出を行った。また, 金沢市への聞き取り調査を通じて, 保全基準の策定後の用水の整 備, 利用, 管理の取り組みの把握を行った。

審議会では, 用水景観の保全と積極的な用水利用の提案に向け
て,「多面的な利用の調整」「利用と管理の調整」「文化背景や立 地場所」などの多様な観点からの議論が行われ，その多くが用水 の保全基準・要綱に反映されていることが分かった。例えば，審 議会の用水の「多面的な利用の調整」に関する議論の中では, 水 生生物・蛍の生息環境の保全や, 観光資源化に向けた年間通水が 提案されているが (表一 6 ), これらは,「水生生物に配慮した構 造 (中村高畠, 長坂, 小坂, 樋俣, 大桑, 雀谷, 河原市用水) 」, 「蛍への配慮・里化（雀谷川）」,「年間通水や水量増を図る（辰巳 用水)」などとして，保全基準・要綱の中に記述されている（表 - 5 )。また，「利用と管理の調整」で対応が検討されていた市民 への教育や啓蒙に関しては（表- 7 ），大桑用水の保全基準で「蛍 の生息環境保全に関して住民の理解と協力を得る」と明示され, 「文化背景や立地場所」で議題に挙がっていた歴史や文化的背景 の保全や市民の用水利用の向上についても（表－8），「農村・田 園風景との調和（河原市用水）」「学べる場の創出（小坂用水）」 といった要綱への反映が確認できる。ただし, 審議会で議論や提 案が行われた事項が全て保全基準に記載されているわけではない。 例えば, 審議会で議論されていた, 遮光版の設置 (河原市用水), 安全対策上の柵の設置（鞍月用水）などの技術的な対応は保全基 準の中には記載されていない。また，ホタルに配慮した清掃（雀 谷川), カワニナの盗掘対策 (大桑用水), 流速対策 (小坂用水), 町会との連携（大野庄用水）などに関する具体的な管理や連携の 方法も保全基準・要綱のなかには明示されていない。

一方, 保全基準・要綱の策定と整備事業の実施の関係性に着目 してみると, 保全基準の策定が, 整備事業の実施に直接的に結び ついていないことも分かった。実際, 保全基準の策定後に整備事 業が行われた保全用水は, 歴史的価值が高く市民とのかかわりが 強いとされる第 1 次指定の用水に限られている。このようにすべ ての保全用水で整備事業が行われていない理由は，予算の制約や 事業実施の大幅な遅れというよりは, 多くの保全基準が用水の利 用と管理を調整して現況の景観を保全することや，将来の開発を 未然に防ぐことに主眼を置いているためだと考えられる。実際, 第 2 次指定以降の用水の保全基準は，用水保全の目指すべき将来 像を提示するという性格が強く, 例えば沼田用水では, 「野町界 隈の街並み形成の骨格をなすとともに, 沿川の生活環境に調和し た用水空間を保全する」と記載されるなど，そもそも即時の整備 事業を必要としていない。そして整備事業の実施の代わりに，金 沢市は, 日常的な管理や更なる用水の利用のための複数の事業を 実施している (4 章 (2)（3）を参照)。

以上のように，金沢市は審議会を中心に，用水の多様な利用と 管理の方策を即地的に協議し，それらを保全基準・要綱として提 示することで，将来的な利用と管理の混乱を未然に防ぐとともに， 用水保全のハード整備とソフト事業に多角的に取り組んでいるこ とが分かった。ただし，このような用水保全条例の運用だけでは， 日常的な用水管理を行う農家などの負担が軽減されるわけではな い。用水保全条例の運用によって, 用水保全の目指すべき方向性 を提示していくと共に，農家数が減少するなかでの用水の日常的 な清掃や整備を支える仕組みを再構築していくことが益々求めら れていくだろう。そしてこの結果として, 都市と農村の関係性の 変化に応じて動態的に変化する, 用水の利用や管理が持続的に達 成されることが望まれる。

\section{(2) 今後の課題}

今後の研究課題は, 以下の 3 点が挙げられる。 1 点目が, 用水 保全条例の運用による用水保全の実効性を評価することである。 この点に関して, 本研究では整備事業の実施状況の明示しか行え ていない。今後は, 各用水が保全基準に従った保全を行えている かを, 実地調査などをもとに分析していく必要がある。2 点目が, 金沢市の保全指定が行われていない用水の整備状況を調查するこ 
とである。これらの用水と, 保全指定された用水を比較すること で，保全指定の効果や課題がさらに明確になると考えられる。3 点目が，他地域の用水保全の取り組みと金沢市の取り組みとの比 較を行うことである。本研究は, 金沢市のみを対象とした調査で あったが, 他地域との比較を行うことで, 部分的に定量的な評価 などが可能となると推察され, 用水保全の運用に対する新たな知 見が獲得できると考えている。

謝辞：本研究の調査にあたっては, 金沢市歴史都市推進課, 内水 整備課, 農業基盤整備課からの資料提供をはじめとした多大なサ ポートを頂いた。なお, 本研究は, 科研費若手 (19K20505) と 2018 年公益財団法人大林財団の研究助成を受けて実施したもの である。

\section{補注及び引用文献}

1）農林水産省：農業用水の多面的役割

https://www.maff.go.jp/j/nousin/mizu/kurasi_agwater/k_ function/（最終閲覧：2020.2.1）

2）国土交通省（2016）：日本の水資源

http://www.mlit.go.jp/tochimizushigen/mizsei/c_actual/ actual03.html（最終閲覧：2020.2.1）

3）農林水産省：別紙 地域用水環境整備事業に係る運用 https://www.maff.go.jp/j/nousin/seibi/pdf/bessi15.pdf (最終閲覧：2020.2.1）

4）国土交通省（2006）：環境用水に係る水利使用許可の取扱いについて https://www.mlit.go.jp/river/shishin_guideline/kankyo/ press/200601_06/060320/060320_tutatu.html（最終閲覧：2020.2.1）

5）ため池の保全条例などは兵庫県など複数存在しているが, 用水の保全 条例は管見のところ金沢市にしか存在していない。この金沢市保全条 例に関する先行研究は, 補注 7), 8）などがある。

6）金沢市：用水の保全 金沢の用水

https://www4.city.kanazawa.lg.jp/11107/keikan/yousui/yo_map. html（最終閲覧 : 2020.2.1）

7）山下亜紀郎（2018）：金沢市における用水保全施策の特徵と用水の地 域的役割：人文地理学研究 $38,1-12$

8）林大樹・越沢明・坂井文（2012）：金沢市の歴史まちづくりにおける 用水の保全と活用：日本建築学会技術報告集 18(40), 1057-1060

9）松尾芳雄（2001）：農業施設の地域用水利用のための配慮事項と整備 計画手法：農業土木学会誌 70(2), 95-99

10）奥島修二・伊藤清栄・長利洋・山本勝利（2004）：多面的機能維持の ための水路管理に要する費用負担の事例：農業土木学会論文集 234 , 153-159

11）中村好男（2018）：農業構造の変革および農村環境の創成にかかわる 土地改良区の役割：東京農大農学集報 63(1), 10-25

12）本田恭子（2011）：農業用排水路の維持管理に対する非農家の参加条 件一農業用水および用排水路の管理形態に着目して：農村計画学会誌,
30 (1) $74-82$

13）井上恵博・有野治・北村達也（2002）：多面的機能の確保をめざした 水路づくり：農業土木学会誌 70(2), 113-116

14）堀裕典・小泉秀樹・大方潤一郎（2007）：シアトル市デザインレビュー 制度運用の実態と課題一建物ボリュームコントロールの視点から：日 本都市計画学会都市計画論文集 42(3), 241-246

15）金沢市教育委員会（2000）：金沢の用水・こばし調查報告書（前編）： 金沢市文化財紀要 $157,296 \mathrm{pp}$

16） 2 章の表や図の作成で参考にした文献資料はそれぞれの文中で具体的 に記述している。主に参照したものは，補注 17)，18），19），20）で 記載した資料や書籍である。

17）表－２は，金沢市が発行するパンフレット「金沢用水めぐり〜保全用 水と怱構堀〜」(金沢市歴史建造物整備課用水・総構堀保全室, 2015）「歩いてみまっし用水の街『金沢』」」（金沢市歴史建造物整備課 用水・総構堀保全室，2015）及び補注 6）の金沢市ホームページを参 照して, 各用水の成り立ちと現在の利用に関する部分を拢き出したう えで，筆者が文意を変えずに記述を簡略化して作成したものである。

18）金沢市の用水保全を中心とした景観行政の経緯に関しては，伝統環境 保全条例制定 50 周年を記念した冊子「金沢景観五十年のあゆみ」（金 沢市，2018）を参考にしている。

19）表－3 は，金沢市が発行するそれぞれの都市計画文書（金沢市都市計 画マスタープラン，金沢市景観計画など）で，「用水」「用水路」とい う用語を検索し，該当する記述箇所を抜き出したものである。なお， 表中の記述を簡易化するための編集が著者により行われている。

20）「用水保全基準及び用水保全要綱」は，金沢市用水保全条例に従って 金沢市が決定した保全基準を記した文書である。本研究では，金沢市 へのヒアリング調査時に金沢市役所で閲覧を行った。

21）これまでに，金沢市職員，県職員，農林水産省北陸農政局職員のほか, 大学教員, 郷土史家や, 金沢市経済同友会, 用水連合会, 農業委員会, 観光協会などに所属する方が委員を務めている。

22）例えば， 6 次指定の河原市用水についての審議にある「長坂用水もそ うだが，用水の片側が山で反対が谷となっていると，山側からの雨水 排水を用水路がキャッチしその処理もしなければならない。」という 発言は「兩岸に山と谷があり雨水排水機能を担保せざるを得ない」と 簡易化できる。この要旨と似た意見をまとめて，「用水の地理的制約 と保全基準の関係」というグループを作った。このようなグループ化 を他の発言についても行い, 用水の文化背景や立地場所が整備方針に 与えた影響に関する記述をまとめ, 表一 8 を作成した。表一 6,7 む 同様の手順に従って作成を行っている。

23）山出保（2018）：まちづくり都市 金沢：岩波書店, $224 \mathrm{pp}$ 山出氏は上記の著書において, 用水保全の取り組みを「コミュニティ の再生」を意図して行ったものだと回顧している。

24）土地所有などの周辺環境が理由として整備が進んでいない場所は, 辰 巳用水の区間 6 (県立文教会館周辺) などである。

25）土地改良区の維持管理に対する金沢市からの補助金などはある。 (2020.3.23 受付，2021.2.27 受理) 